\title{
On the Seasonal Signal of the Filchner Overflow, Weddell Sea, Antarctica
}

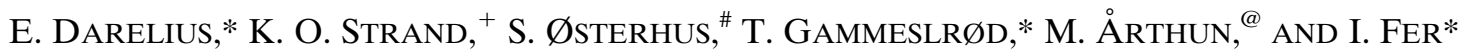 \\ * Geophysical Institute, University of Bergen, and Bjerknes Centre for Climate Research, Bergen, Norway \\ ${ }^{+}$Norwegian Meteorological Institute, Bergen, Norway \\ ${ }^{\#}$ Uni Climate, Uni Research, and Bjerknes Centre for Climate Research, Bergen, Norway \\ ${ }^{\circledR}$ British Antarctic Survey, Cambridge, United Kingdom
}

(Manuscript received 14 August 2013, in final form 7 January 2014)

\begin{abstract}
The cold ice shelf water (ISW) that formed below the Filchner-Ronne Ice Shelf in the southwestern Weddell Sea, Antarctica, escapes the ice shelf cavity through the Filchner Depression and spills over its sill at a rate of 1.6 Sverdrups $\left(\mathrm{Sv} ; 1 \mathrm{~Sv} \equiv 10^{6} \mathrm{~m}^{3} \mathrm{~s}^{-1}\right)$, thus contributing significantly to the production of Weddell Sea Bottom Water. Here, the authors examine all available observational data from the region-including five year-long time series of mooring data from the Filchner sill- to examine the seasonal variability of the outflow. The temperature of the ISW outflow is found to vary seasonally by $0.07^{\circ} \mathrm{C}$ with a maximum in April. The accompanying signal in salinity causes a seasonal signal in density of $0.03-0.04 \mathrm{~kg} \mathrm{~m}^{-3}$, potentially changing the penetration depth of the ISW plume by more than $500 \mathrm{~m}$. Contrary to recent modeling, the observations show no seasonal variability in outflow velocity. The seasonality observed at the sill is, at least partly, due to the admixture of high-salinity shelf water from the Berkner Bank. Observations and numerical modeling suggest, however, seasonal signals in the circulation upstream (i.e., in the ice shelf cavity and in the Filchner Depression) that-although processes and linkages are unclear-are likely to contribute to the seasonal signal observed at the sill. In the plume region downstream of the sill, the source variability is apparent only within the very densest portions of the ISW plume. In the more diluted part of the plume, the source variability is overcome by the seasonality in the properties of the water entrained at the shelf break. This will have implications for the properties of the generated bottom waters.
\end{abstract}

\section{Introduction}

Antarctic Bottom Water (AABW) spreads out from its source regions and is found at the bottom of the majority of the world's oceans (Johnson 2008). The Weddell Sea is traditionally considered central in the formation of AABW, and although new sources of bottom water have been discovered (e.g., Ohshima et al. 2013), it is still viewed as the major source, contributing about $40 \%$ of the total production (Meredith 2013). The dense waters are formed through air-sea ice interaction on the continental shelves and below the ice shelves in the southern Weddell Sea, a region where severe ice conditions and weather make fieldwork and observations difficult. The number of direct observations is very limited, and, as a consequence, our knowledge about interannual and seasonal variability in the production of

Corresponding author address: E. Darelius, Geophysical Institute, University of Bergen, Alleg. 70, 5007 Bergen, Norway.

E-mail: darelius@gfi.uib.no these waters is relatively poor. Results from recent numerical modeling suggest that there is a seasonality in the outflow of dense ice shelf water (ISW) from the Filchner Depression (FD; see Fig. 1 for location; Kida 2011; Wang et al. 2012), one of the major sources of Weddell Sea Bottom Water (Foldvik et al. 2004, hereafter F04). Here, we synthesize observational data from the region-the Filchner Depression, the Filchner sill, and the plume region downstream-to examine the seasonal variability of the Filchner overflow.

Processes occurring beneath the Filchner-Ronne Ice Shelf (FRIS; see Fig. 1) and on the adjacent continental shelf produce two water masses, high-salinity shelf water (HSSW; see Fig. 2 for location of water masses in temperature-salinity space) and ISW, that are dense enough to descend the continental slope and contribute to the formation of Weddell Sea Deep Water (WSDW) and Weddell Sea Bottom Water (WSBW), precursors to AABW. HSSW is formed from modified warm deep water (MWDW) and other shelf waters on the continental shelf through cooling and brine rejection (Nicholls 


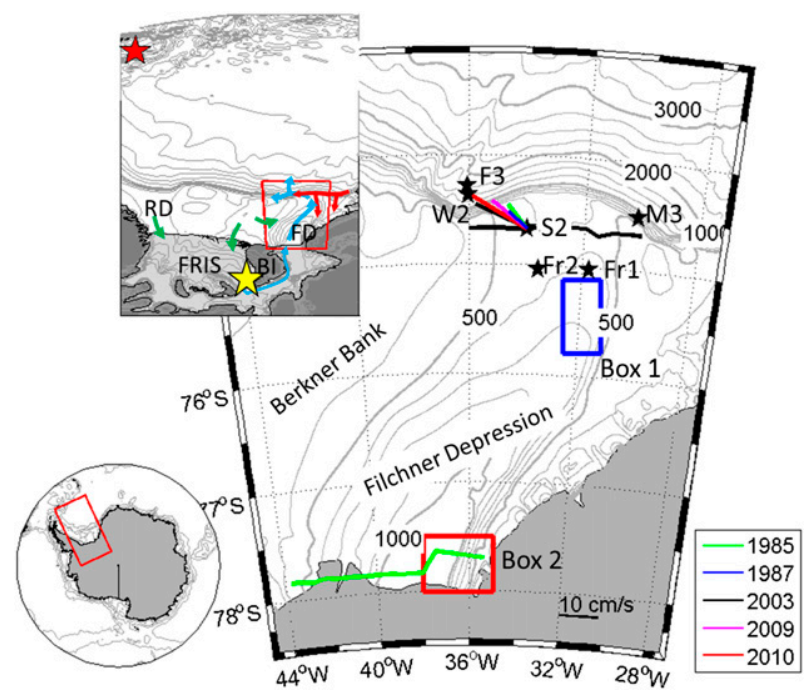

FIG. 1. Map over the study area showing the position of the moorings (labeled black stars), the mean current from the S2 deployments (colored according to the legend, velocity scale in the lower-right corner), Box 1 (blue square), Box 2 (red square), and CTD sections at the Filchner front in 2013 (green line; data shown in Fig. 6 , described in greater detail below) and at the sill in 2003 (black line; data shown in Fig. 3, described in greater detail below). Isobaths (from GEBCO; www.gebco.net) are shown every $100 \mathrm{~m}$ (gray lines) with every $500 \mathrm{~m}$ in dark gray. The upper inset shows the location of the study area (red box) and the FRIS, Berkner Island (BI), FD, Ronne Depression (RD), the mooring site close to the Orkney Passage (red star; Gordon et al. 2010), and Site 5 (yellow star; Nicholls et al. 2001; Nicholls and Østerhus 2004). Arrows indicate the path of ISW (blue), HSSW (green), and MWDW (red). The lower inset shows the location of the region (red box) shown in the upper inset.

et al. 2009). It flows both northward, participating directly in deep water formation as it mixes with warm deep water (WDW) and MWDW at the shelf break (Gill 1973), and southward into the FRIS cavity. Although at the surface freezing point $T_{f}$, the depression of the in situ freezing point with increasing pressure enables the HSSW flowing into the cavity to melt ice at depth, resulting in a cooling and freshening of the water. Through the interaction with the glacial ice within the cavity, HSSW is transformed to potentially supercooled (potential temperature $\theta<T_{f}$ ) ISW. When melting (or freezing) ice within the ice shelf cavity, the characteristics of the seawater will evolve in potential temperature and salinity (i.e., $\theta-S$ ) space following a straight line-a Gade line (Gade 1979; Jenkins 1999) — that passes through the point $\left(S_{0}, T_{f}\right)$, where $S_{0}$ is the salinity of the source water. The Gade line has a gradient of $2.4^{\circ}-2.8^{\circ} \mathrm{C}$ depending on the degree of heat diffusing into the ice (Nicholls et al. 2009). Supercooled water with gradients smaller than $2.4^{\circ} \mathrm{C}$ or larger than $2.8^{\circ} \mathrm{C}$ in $\theta-S$ space would then indicate a mixture of ISW and a second water mass (Nøst et al. 1998, hereafter N98).

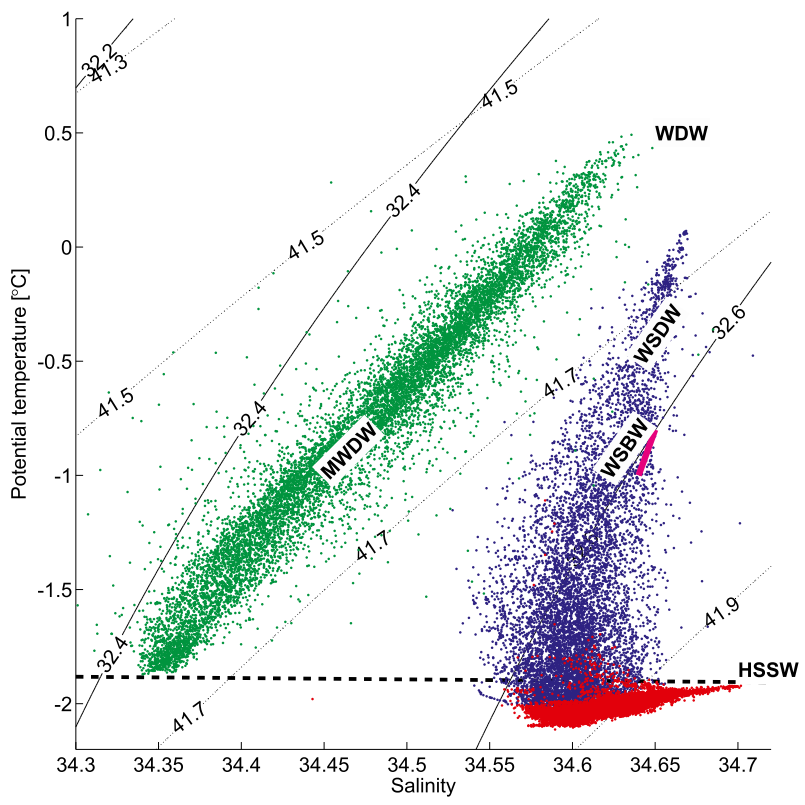

FIG. 2. The $\theta-S$ diagram showing data from S2 in 2009 and 2010 (red; see also Fig. 6, described in greater detail below), M3 (green; $75 \mathrm{mab}$ ), and F3 (blue; $9 \mathrm{mab}$ ) together with the seasonal variability observed in the vicinity of the Orkney Passage (short magenta line near $1^{\circ} \mathrm{C}$ and 34.65 ; Gordon et al. 2010). For reference, the surface freezing point (dashed black line) and isopycnals referenced to 1000 dbar (slightly deeper than sill depth; solid lines) and $3000 \mathrm{dbar}$ (depth of Orkney Passage is $3500 \mathrm{~m}$; dotted lines) are included.

The ISW formed below FRIS exits the cavity through the Filchner Depression (see Fig. 1) and spills over the sill at a rate of 1.6 Sverdrups $\left(\mathrm{Sv} ; 1 \mathrm{~Sv} \equiv 10^{-6} \mathrm{~m}^{3} \mathrm{~s}^{-1}\right.$; F04). At the sill, ISW is typically found in a 150-m-thick layer (F04), and outflow velocities at mooring location S2 (see Fig. 1 for location), located roughly in the center of the outflow (Fig. 3), are on the order of $10 \mathrm{~cm} \mathrm{~s}^{-1}$. Once on the continental slope, the ISW forms a dense plume that flows westward along the slope. Part of the dense plume is steered downslope by ridges crosscutting the slope (Darelius and Wåhlin 2007), and it is believed that the Filchner overflow contributes to the formation of WSBW rather than WSDW (Gordon 1998; Fahrbach et al. 1995). The plume region and the continental slope northeast of the Filchner Depression is characterized by substantial mesoscale variability (Darelius et al. 2009; Jensen et al. 2013), probably linked to continental shelf waves (Jensen et al. 2013).

HSSW formed west of the Filchner Depression on the Berkner Bank (see Fig. 1), where salinities above 34.7 have been observed (Gammelsrød and Slotsvik 1981; Gammelsrød et al. 1994), flows into the depression (Carmack and Foster 1975; N98) and southward into the FRIS cavity (N98). The residence time of HSSW in the Filchner Depression is relatively short, less than two 


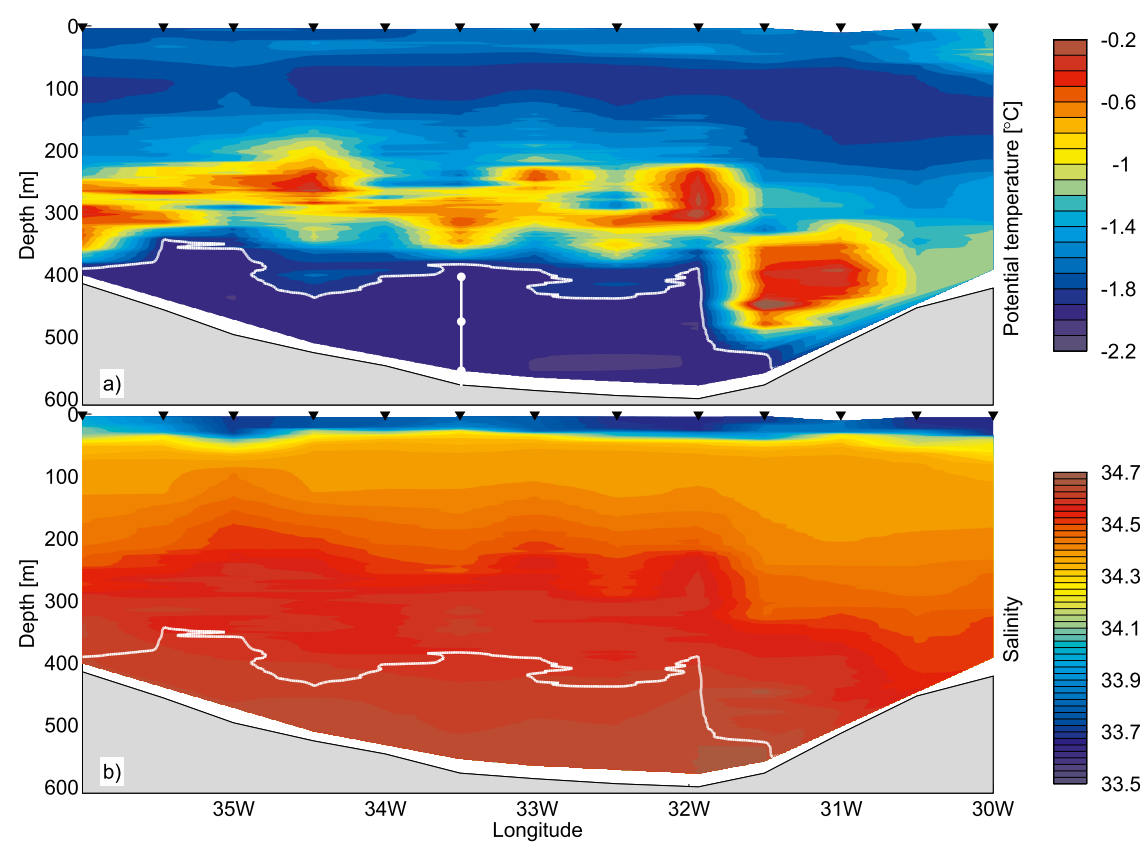

FIG. 3. Sections of (a) $\theta$ and (b) $S$ across the Filchner sill obtained in 2003 (Abrahamsen et al. 2003), including the position of S2 (white circles). The $-1.9^{\circ} \mathrm{C}$ isotherm, delineating the boundary ISW is highlighted (white lines). The location of the CTD section is shown in Fig. 1.

years (N98). In 1986, three giant icebergs (A22-A24) broke off from the front of the Filchner Ice Shelf and stranded on the Berkner Bank, modifying the HSSW production and paths; observations show that no HSSW entered the FD during the following years (N98), and modeling suggests that the HSSW instead flowed northward toward the Filchner sill and the continental slope (Grosfeld et al. 2001). In 1990, iceberg A24 came ungrounded and drifted northward. Icebergs A22 and A23 broke in two in 1994 and 1991 and drifted northward during the following years, but the main part of A23 remained grounded until 2009.

The prevailing easterly winds in the southern Weddell Sea cause a converging southward Ekman transport of surface waters and a depression of the pycnocline along the shelf break (Sverdrup 1954). The strength of the wind, and thus the depression of the isopycnals, varies seasonally with strong winds (and anomalously deep pycnocline) during the austral winter months (Wang et al. 2012). The variable depth of the isopycnals at the shelf break gives rise to a seasonal inflow of MWDW across the Filchner sill in the summer months when the pycnocline is shallow (Årthun et al. 2012). The variability in density at the shelf break is suggested by numerical models (Kida 2011; Wang et al. 2012) to also affect the outflow: because the condition within the Filchner Depression is assumed to be constant, the variability in the ambient water leads to a seasonality in the density difference driving the geostrophically balanced outflow and thus to a seasonality in the volume flux of dense water across the sill.

In this paper, we examine the seasonal signal in the ISW outflow based on five, 1-yr-long time series, spanning the period from 1985 to 2010 , from the mooring S2 located at the Filchner sill at about 550-m depth (Fig. 1). Additional mooring records (see, e.g., F04), traditional hydrographic data, and conductivity-temperature-depth (CTD) data collected by sensors attached to Weddell seals in February-September 2011 (Årthun et al. 2012, 2013) from the regions are revisited to investigate the origin of the signal and its propagation downstream of the sill.

\section{Data and methods}

Time series data have been obtained at the location S2 (Fig. 1) at about 550-m depth on the Filchner sill where moorings have been deployed in 1977, 1985, 1987, 2003, and 2009-11. The moorings are detailed in Table 1 . The 1977 deployment is omitted from the analysis because drift in the temperature sensors cannot be excluded (A. Foldvik 2012, personal communication), leaving five, 1-yr-long data records on the sill. Note that the deployments prior to 2003 were roughly $10 \mathrm{~km}$ farther west of later deployments (Table 1). The moorings were equipped with sensors manufactured by Aanderaa 
TABLE 1 . Summary of S2 moorings: $V=$ velocity, $T=$ temperature, and $S=$ salinity. Superscripts give the number of sensors and manufacturer: $A=$ AADI and $S=$ Sea-Bird.

\begin{tabular}{lllllrr}
\hline \hline Year & Height $(\mathrm{mab})$ & Data & Record days & Lat & Lon & ${\text { Mean speed }\left(\mathrm{cm} \mathrm{s}^{-1}\right)}^{2}$ \\
\hline 1985 & $25 / 100 / 190$ & $V^{A} T^{A}$ & $371 / 283 / 258$ & $77^{\circ} 40^{\prime} \mathrm{S}$ & $33^{\circ} 56^{\prime} \mathrm{W}$ & 8 \\
1987 & $25 / 100$ & $V^{A} T^{A}$ & $352 / 404$ & $77^{\circ} 40^{\prime} \mathrm{S}$ & $34^{\circ} 00^{\prime} \mathrm{W}$ & 6 \\
2003 & $27 / 102$ & $V^{A} T^{A}$ & $421 / 747$ & $77^{\circ} 40^{\prime} \mathrm{S}$ & $33^{\circ} 28^{\prime} \mathrm{W}$ & 14 \\
2009 & $0-41^{*}$ & $V^{A} T^{2 A} S^{2 A}$ & $356^{* *}$ & $77^{\circ} 39^{\prime} \mathrm{S}$ & $33^{\circ} 33^{\prime} \mathrm{W}$ & 11 \\
2010 & $25 / 104 / 176$ & $V^{A} T^{S} S^{S}$ & $364 / 364 / 182$ & $77^{\circ} 38^{\prime} \mathrm{S}$ & $33^{\circ} 30^{\prime} \mathrm{W}$ & 16 \\
\hline
\end{tabular}

* Bottom frame with a 600-kHz upward-looking acoustic Doppler current profiler (4-m bins).

** Only daily velocity measurements.

Data Instruments (AADI): recording current meters (RCM4, RCM7, and RCM9) and by Sea-Bird Electronics (SBE) MicroCAT (SBE37). Instruments deployed prior to 2009 are calibrated as described in F04, except for the 1987 data, where a calibration error was detected and corrected. In addition, data from 1987 are corrected by an offset against nearby CTD profiles obtained during deployment (Strand 2011). Predeployment factory calibrations are used for sensors in the 2009 and 2010 deployments. To remove the influence of MWDW intrusions (see section 3) and to capture the overflow temperature, the calculation of monthly-mean overflow temperatures exclude data with $T>-1.9^{\circ} \mathrm{C}$. The percentages of time $t$ that an instrument is surrounded by MWDW ( $T>-1.7^{\circ} \mathrm{C}$; Foster and Carmack 1976) and ISW $\left(T<-1.9^{\circ} \mathrm{C}\right)$ are given by $\% t_{\mathrm{MWDW}}$ and $\% t_{\mathrm{ISW}}$, respectively. Current measurements are presented as outflow velocity anomalies $v^{\prime}=v^{*}-\overline{v^{*}}$, where $v^{*}$ is the hourly measurements in the direction of the mean current and $\overline{v^{*}}$ is the deployment mean current at the deepest instrument. To avoid the influence of the stranded icebergs (N98; see below), the records from 1987 are excluded from the calculations of the mean seasonal signals.

In addition to the S2 records, data from mooring M3 (Fig. 1; Jensen et al. 2013) deployed at 725-m depth on the upper slope east of the Filchner sill in 2009 and moorings F3 (F04) and W2 deployed in the plume path on the continental slope west of Filchner Depression are included in the analysis. The moorings are detailed in Table 2 and their locations are shown in Fig. 1. Analogously to \% $t_{\text {MWDW }}$ and $\% t_{\text {ISW }}$ defined above, $\% t_{\text {plume }}$ denotes the percentage of time that a mooring on the slope is surrounded by plume water, here defined as $T<-1.5^{\circ} \mathrm{C}$.

CTD data are collected during the Global Interactions of the Antarctic Ice Sheet-Response of the Ice-Shelf Ocean System to Climate (GIANTS-RISOC) cruise in 2003 (Abrahamsen et al. 2003), cruise ES060 in 2013 (Darelius 2013), and sensors attached to Weddell seals in 2011 (hereafter referred to as "seal data"; Årthun et al. 2012, 2013). The CTD profiles collected by the seals consist of 20 measurements, equally spaced in the vertical, and have an accuracy of about $0.005^{\circ} \mathrm{C}$ and 0.02 in temperature and salinity, respectively (Boehme et al. 2009). Profiles deeper than $650 \mathrm{~m}$ from Box 1 (75.1 ${ }^{\circ}$ $75.8^{\circ} \mathrm{S}, 31.3^{\circ}-32.5^{\circ} \mathrm{W}$; see Fig. 1 for location) are linearly interpolated to $1-\mathrm{m}$ resolution before monthly-mean profiles are calculated. The dive depths agree to within $35 \mathrm{~m}$ (standard deviation of the difference is $17 \mathrm{~m}$ ) with depths interpolated from the General Bathymetry Chart of the Oceans (GEBCO). All temperature profiles from September (one seal) are corrected by a constant offset of $-0.03^{\circ} \mathrm{C}$ (inferred from the freezing point in the surface layer).

\section{Results}

\section{a. Seasonality on the Filchner sill}

\section{1) Temperature AND SALINITY}

Figures 4 and 5 show the time series from S2 and the mean seasonal signals, respectively. The time series of in situ temperature at $\mathrm{S} 2,25 \mathrm{~m}$ above bottom (mab) show that temperatures are generally below the surface freezing point, and the lower part of the mooring is surrounded by ISW more than $97 \%$ of the time (Fig. $4 a$ ). Occasional intrusions $(<1 \%$ of the time at $25 \mathrm{mab}$ ) of MWDW cause the temperature to rise well above $T_{f}$. The records from 1987 differ significantly from the other deployments: beginning in August, the temperature at 25 mab rises

TABLE 2. Summary of moorings deployed on the slope and in the Filchner Depression.

\begin{tabular}{|c|c|c|c|c|c|c|}
\hline Name & Year & $\begin{array}{c}\text { Depth } \\
(\mathrm{m})\end{array}$ & Lat & Lon & $\begin{array}{c}\% \\
t_{\text {plume }}\end{array}$ & Reference \\
\hline Fr1 & 1995 & 610 & $75^{\circ} 01^{\prime} \mathrm{S}$ & $31^{\circ} 46^{\prime} \mathrm{W}$ & - & F04 \\
\hline Fr2 & 1995 & 574 & $75^{\circ} 02^{\prime} \mathrm{S}$ & $33^{\circ} 33^{\prime} \mathrm{W}$ & - & F04 \\
\hline F3 & 1998 & 1637 & $74^{\circ} 17^{\prime} \mathrm{S}$ & $36^{\circ} 04^{\prime} \mathrm{W}$ & 60 & F04 \\
\hline M3 & 2009 & 753 & $74^{\circ} 31^{\prime} \mathrm{S}$ & $30^{\circ} 10^{\prime} \mathrm{W}$ & - & $\begin{array}{c}\text { Jensen } \\
\text { et al. } \\
\text { (2013) }\end{array}$ \\
\hline $\mathrm{W} 2$ & 2010 & 1411 & $74^{\circ} 22^{\prime} \mathrm{S}$ & $36^{\circ} 01^{\prime} \mathrm{W}$ & 57 & This study \\
\hline
\end{tabular}



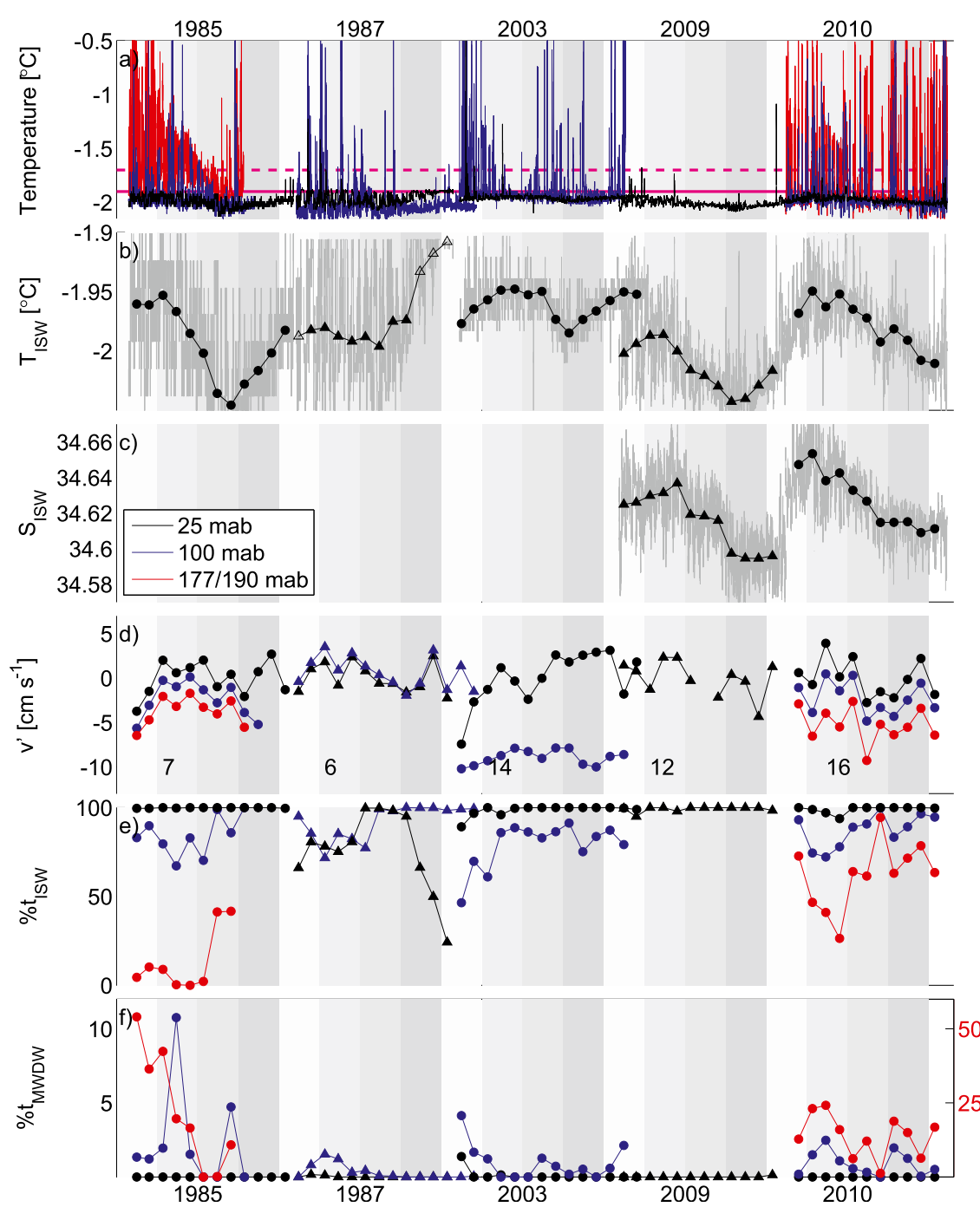

FIG. 4. Time series of (a) temperature $\left({ }^{\circ} \mathrm{C}\right)$ and monthly-mean ISW (b) temperature $T_{\text {ISW }}$, (c) salinity $S_{\text {ISW, }}$, (d) overflow velocity anomaly $\left(\mathrm{cm} \mathrm{s}^{-1}\right)$, and percentage of time that the temperature indicates the presence of (e) ISW water and (f) MWDW at mooring S2 from 1/25 (black), 100 (blue), and 177/190 mab (red). For clarity, the time series from 175 to $190 \mathrm{mab}$ (red) in (f) is scaled by a factor of 0.2 and follows the $y$ axis to the right. To separate overlapping time series in (a)-(f) (caused by the noncontinuous $x$ axis), the years are marked with alternating circles and triangles. Nonfilled symbols in (b) indicate that $<25 \%$ of the data is ISW. The ISW (magenta) and MWDW (dashed magenta) cutoff temperatures are included in (a). Unfiltered temperature and salinity data are included (light gray) in (b)-(c). Numbers in (d) give the deployment mean outflow current at $25 \mathrm{mab}\left(\mathrm{cm} \mathrm{s}^{-1}\right)$. To emphasize the seasons, the background color darkens from white (January-March) to light gray (April-June) and gray (JulySeptember) to dark gray (October-December). The legend in (c) is valid for all panels.

to stabilize around $-1.9^{\circ} \mathrm{C}$, the surface freezing point, suggesting that the instrument is surrounded by HSSW (Figs. 4a,b). The fraction of the time that the instrument is surrounded by ISW decreases accordingly (Fig. 4e). Meanwhile, the temperature at 100 mab remains around $-2^{\circ} \mathrm{C}$. The measurements thus indicate that toward the end of 1987, there is an outflow of relatively pure HSSW in a layer close to the bottom, while ISW is found in a layer above it. This confirms the findings of Grosfeld et al. (2001) and N98 that the icebergs stranded on the Berkner Bank caused the HSSW formed there to change its path and flow north-northeastward toward the Filchner sill and the deep ocean, rather than eastward into the Filchner Depression.

With the exception of 1987, the temperature records from S2 reveal a seasonal signal with a minimum in 

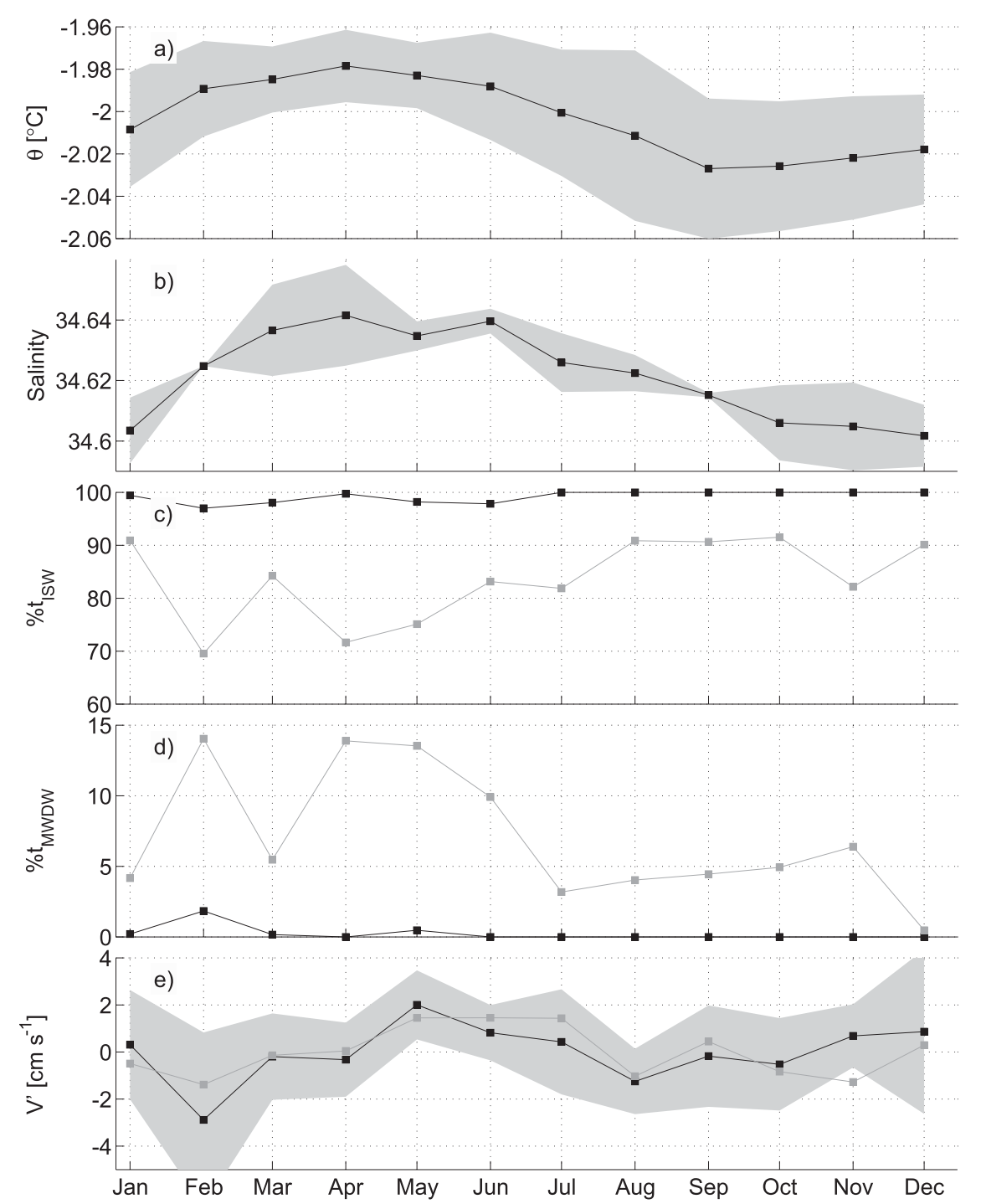

FIG. 5. Mean seasonal signal from the 1985, 2003, 2009, and 2010 deployments of ISW (a) potential temperature $\left({ }^{\circ} \mathrm{C}\right)$ and (b) salinity from 25 mab. Mean seasonal signal of (c) $\% t_{\text {ISW }}$, (d) $\% t_{\text {MWDW }}$, and mean seasonal signal of (e) outflow velocity anomaly $\left(\mathrm{cm} \mathrm{s}^{-1}\right)$. Measurements are from 25 (black filled boxes) to $100 \mathrm{mab}$ (gray filled boxes). The gray envelope in (a),(b), and (e) shows the std dev of 25-mab measurements.

September-October and a maximum in April-May with a mean amplitude (here, and hereafter, amplitude refers to peak-to-peak amplitude) of about $0.07^{\circ} \mathrm{C}$ (Figs. 4b, $5 \mathrm{a})$. Salinity changes in concert with temperature, with the temperature maximum coinciding with a maximum in salinity (Figs. 4c, 5b). At low temperatures, density is determined by salinity, and the warmer, more saline "autumn ISW" is hence slightly denser, by $0.03-0.04 \mathrm{~kg} \mathrm{~m}^{-3}$, than the colder and fresher "spring ISW."

Figures 6a-d show data from S2 in 2009 and 2010 from the months with the respective temperature maximum (May and April) and minimum (October and December).
The properties of the water at the sill during the temperature maximum correspond roughly with the water found at similar depths at the Filchner Ice Shelf front in January 2013; they are equally dense or slightly denser. The period with minimum temperature is, especially in 2009, associated with water that in 2013 was found slightly higher up in the water column. Observations falling on a line in $\theta-S$ space are generally the result of mixing between two water masses. For ISW, however, variability along a Gade line is likely to be the result of a varying degree of interaction with the glacial ice, and only lines with a slope that deviates from that of the 

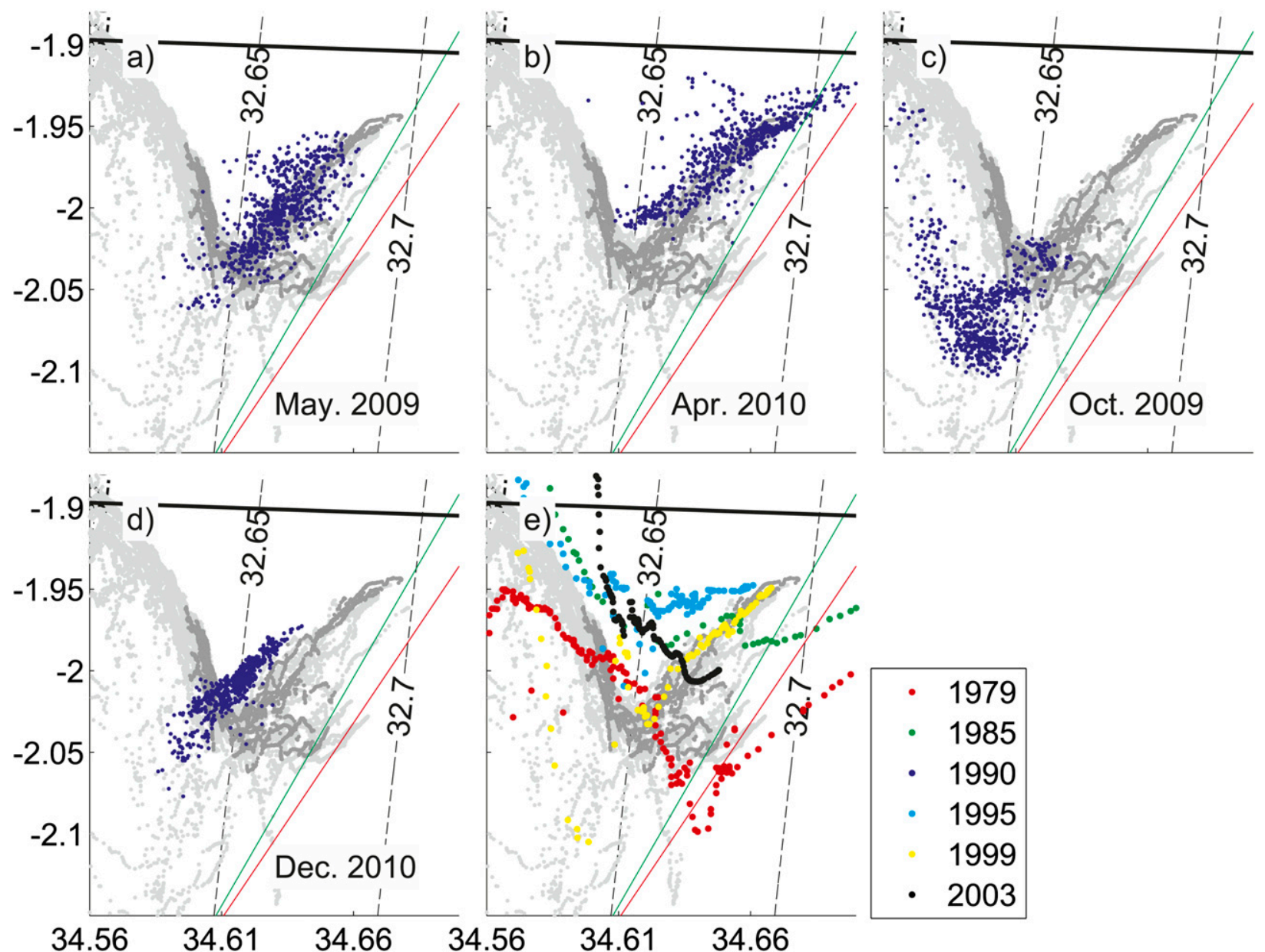

FIG. 6. The $\theta-S$ diagram showing near-bottom observations from S2 in (a) May 2009, (b) April 2010, (c) October 2009, and (d) December 2010. (e) CTD data from the sill obtained in austral summer (January-March) according to the legend. Gade lines with gradients of 2.4 (red line) and 2.8 (green line), the surface freezing point (black line), isopycnals ( $\sigma_{1}$; dashed black lines), and data from stations at the Filchner front [gray dots; data from sill depth $(600-750 \mathrm{~m})$ in dark gray] in 2013 are included for reference.

Gade lines are indicative of mixing (N98). The $\theta-S$ relation in April 2010 deviates from the Gade line and indicates admixture of a warmer and more saline water mass, which must be HSSW because MWDW is too fresh (see Fig. 2). CTD data collected at the Filchner sill during summertime cruises, spread over 4 decades, fall along lines with slopes smaller than that predicted by Gade lines, suggesting that admixture of HSSW at the sill is a common phenomenon during austral summer (Fig. 6e). The slope in the data from May 2009, however, follows the Gade line indicating no admixture of other water masses. In October 2009, the sill data show admixture of surface waters.

\section{2) MWDW INTRUSIONS}

The records show intrusions of MWDW (Figs. 4a,f) more often at the shallower instruments than at the deeper. At $100 \mathrm{mab}$, the instruments are surrounded by
MWDW less than $12 \%$ of the time in any month, while at shallower depths the percentage of MWDW $\left(\% t_{\text {MWDW }}\right)$ is higher-exceeding $50 \%$ in February 1985. There is a tendency for higher values of $\% t_{\text {MwDw }}$ during the summer months when Arthun et al. (2012) observe an inflow of MWDW on the eastern side of the sill. The mean direction of flow during periods of MWDW does not, however, always have a southward, inflowing component (it is southward in 1987 and 2003 and northward in 1985 and 2010; not shown), meaning that S2 to some extent captures a return flow of MWDW that has entered the Filchner Depression farther east.

\section{3) Velocity AND THICKNESS OF THE OUTFLOW}

The velocity measurements at $\mathrm{S} 2$ show a continuous and relatively unidirectional outflow of about $10 \mathrm{~cm} \mathrm{~s}^{-1}$, directed northwest (Fig. 1). Annual-mean values range from 6 to $16 \mathrm{~cm} \mathrm{~s}^{-1}$. The increase from 1987 to 2003 is 

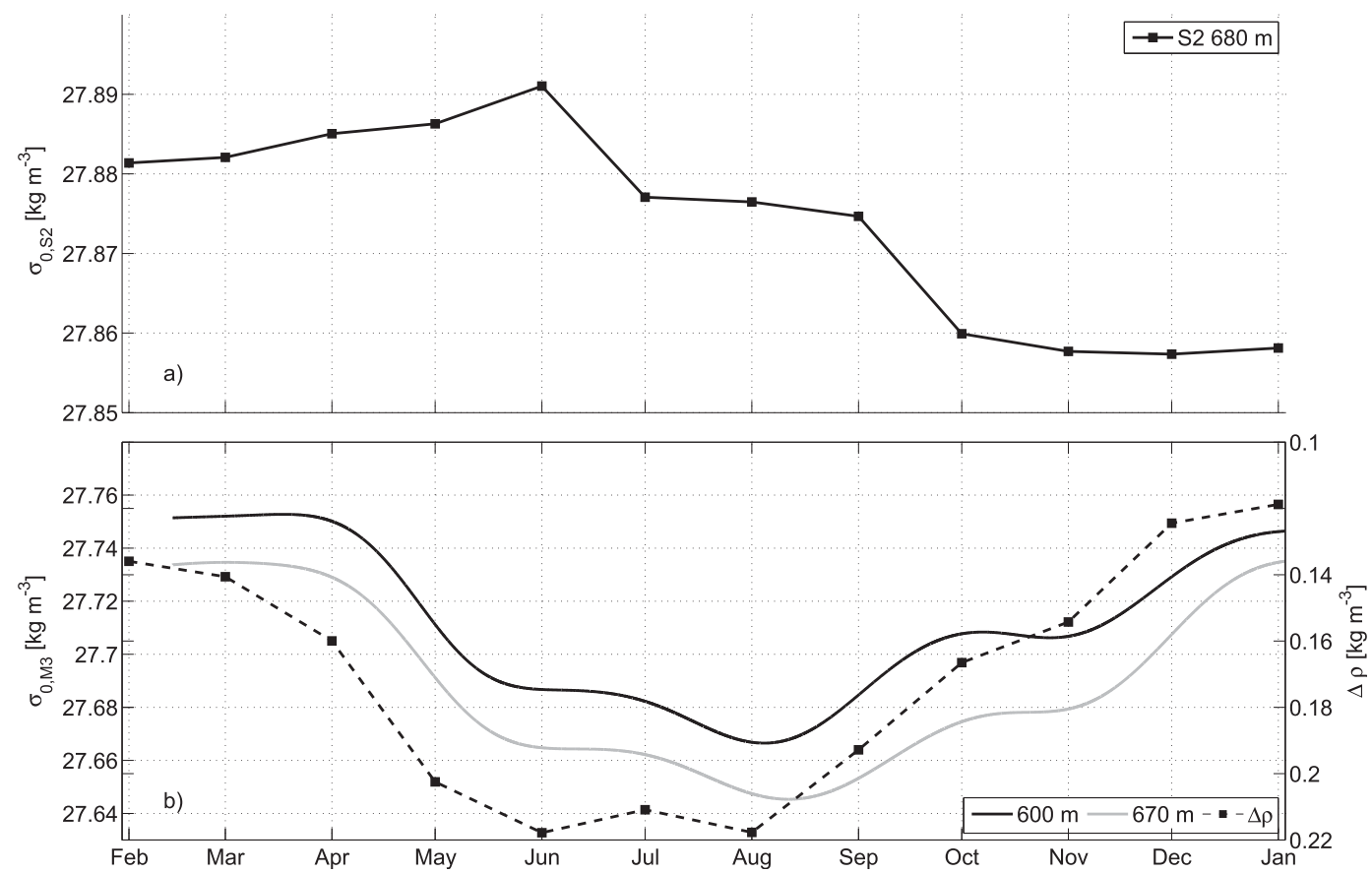

FIG. 7. (a) Monthly-mean density of the outflow at S2. (b) Low-pass-filtered (fourth-order Butterworth filter; cutoff 60 days) density at 600- (black) and 670-m (gray) depth at M3 and the density difference $\Delta \rho$ between the S2 and M3 $670 \mathrm{~m}$ (black squares, dashed line, and right axis). Note the inverse $y$ axis on the right side in (b).

likely linked to the shift in position of the mooring (see methods and Table 1). There is no apparent seasonal signal in the outflow velocity (Figs. 4d, 5e). The increase in $\% t_{\mathrm{ISW}}$, at the shallower instruments (Fig. 4e) during August-January could suggest a thickening of the ISW layer, but the increase is, at least partly, due to changes in the temperature of the ambient water and in the mean ISW temperature: when the water overlying the outflow and/or the outflow itself is colder, a higher degree of mixing is needed to raise the temperature above $-1.9^{\circ} \mathrm{C}$. This is the case, for example, in September, when the water overlying the ISW is at or very close to $T_{f}$.

\section{b. Observations from the sill and the shelf break}

Figure 7 shows concurrent measurements from the sill (S2) and the M3 mooring located close to the shelf break (see Fig. 1). The density at the shelf break (at depths similar to the outflow) show a seasonal variability with a maximum in January-April, a minimum in August, and an amplitude of about $0.09 \mathrm{~kg} \mathrm{~m}^{-3}$. Meanwhile, the amplitude of the seasonal density variations at S2 is $0.03 \mathrm{~kg} \mathrm{~m}^{-3}$ (Fig. 7a). The density difference between the ambient (represented by M3) and the dense outflow $\Delta \rho_{\text {plume }}$ is thus mainly determined by the variability of the shelf break waters and only modified by the density signal of the outflow (Fig. 7b). The deployment mean $\Delta \rho_{\text {plume }}$ is $0.17 \mathrm{~kg} \mathrm{~m}^{-3}$ where the monthly means range from a minimum of $0.12 \mathrm{~kg} \mathrm{~m}^{-3}$ in December-January to a maximum of $0.21 \mathrm{~kg} \mathrm{~m}^{-3}$ in June-August (i.e., almost a doubling).

\section{c. Seasonality in the Filchner Depression}

Wintertime observations from the Filchner Depression are limited to two moorings (Fr1and Fr2 deployed in 1995; F04) and recent profiles collected by Weddell seals (Årthun et al. 2012, 2013). Monthly-mean profiles of temperature and salinity from Box 1 (see Fig. 1 for location) are presented in Figs. 8a and $8 b$. The profiles reveal a layer of ISW extending up to $250-\mathrm{m}$ depth. The ISW layer shows a pronounced temperature minimum located at 500-600-m depth, and it is thickest from February through March and thinnest in September (when it has clearly been eroded from above by convection caused by cooling and brine rejection from ice formation). Note, however, as pointed out above, that because the overlying water in September is at the surface freezing point, a small fraction of upmixed ISW is sufficient to lower the temperature below $-1.9^{\circ} \mathrm{C}$ and cause the water to be defined as ISW. This is likely the explanation for the apparent inconsistency between the seasonal changes in thickness observed in Box 1 and that inferred from $\% t_{\mathrm{ISW}}$ at $\mathrm{S} 2$.

The bottom salinity is higher in February-April than in May-September, and while data from the ISW layer 

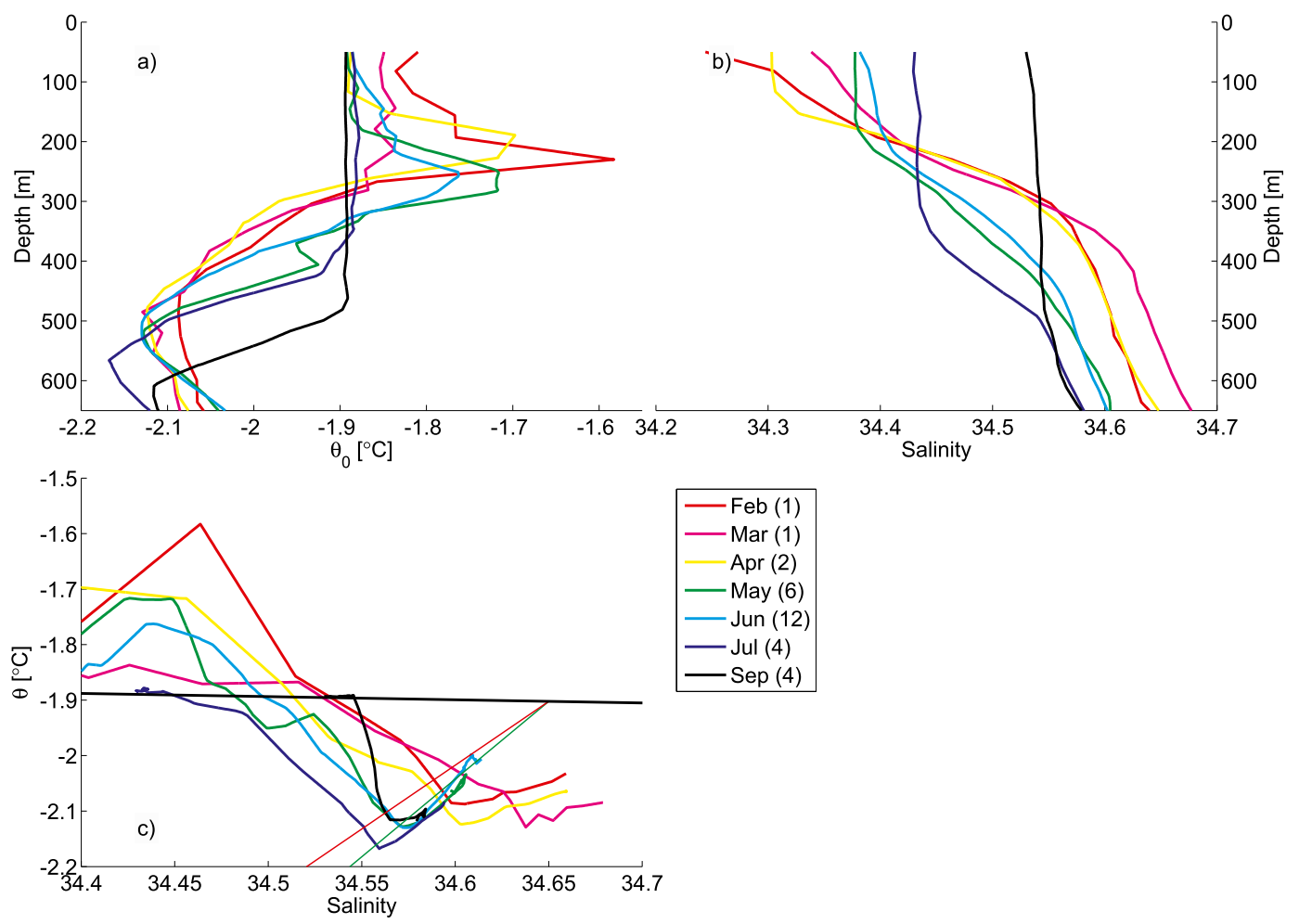

FIG. 8. Monthly-mean profiles of (a) potential temperature, (b) salinity, and (c) $\theta-S$ diagrams using CTD sensors attached to Weddell seals obtained within Box 1 (see Fig. 1 for location). Only data from dives deeper than $650 \mathrm{~m}$ are included in the analysis, and profiles are cut at $650 \mathrm{~m}$. The legend in (c) is valid for (a)-(c), and the number in parenthesis gives the number of profiles collected in that month. Gade lines with gradient 2.4 (red) and 2.8 (green) and the surface freezing point (gray) are included in (c).

in the latter period align with the Gade line (Fig. 8c), data from the earlier period do not. During FebruaryApril the slope in $\theta-S$ space is smaller than the Gade lines, suggesting admixture of a warmer and more saline water mass (HSSW) along the bottom. The depth of the ISW temperature minimum $D_{T_{\min }}$ increases from depths shallower than $500 \mathrm{~m}$ in February to deeper than $600 \mathrm{~m}$ in September, but the result is biased by the apparent preference of the seals to dive in deeper areas later in the season and also by convection eroding the ISW layer from above. The upper layer shows intrusions of MWDW from February through June, centered between $200-$ and $300-m$ depth. The seal data show variability but no obvious seasonal signal in the ISW temperature. While bottom temperatures are highest in May-June, the profiles with the most pronounced temperature minimum (and lowest temperatures) are from July. The mooring data (Fr1-Fr2), on the other hand, show temperature maximum at the deeper instruments in January through April, when there is also a maximum in the northward velocity (Fig. 9). The winter minimum in temperature occurs much later (October-November) in 1995 than in 1996 (June-July).
The CTD profiles obtained by Weddell seals at the Filchner front (Box 2; not shown) are similar to those from Box 1; they all show a pronounced temperature minimum around $-2.2^{\circ} \mathrm{C}$ below which temperature and salinity increase toward the bottom. The $\theta-S$ relation from depths below $D_{T_{\min }}$ follows Gade lines, only deviating toward the bottom in March-May when the slope suggests admixture of more saline HSSW and when the highest bottom temperatures are observed (not shown). From April to June, when the data coverage is relatively good and geographically homogenous, the data show that the depth of the temperature minimum $D_{T_{\min }}$ and the depth of isopycnals below $D_{T_{\min }}$ increase about 80-120 m during 2 months (Fig. 10). During the same period, the mixed layer depth increases from 50 to about $400 \mathrm{~m}$ [as reported by Årthun et al. (2013)]. A large part of the increase in $D_{T_{\min }}$ (and in the mixed layer depth) occurs in late April during an episode with strong easterly winds and is potentially linked to converging Ekman transports and downwelling along the ice shelf front. Contrary to Box 1, where the seals moved to deeper water during winter, there is no similar trend in depth in Box 2, and there is no correlation between 


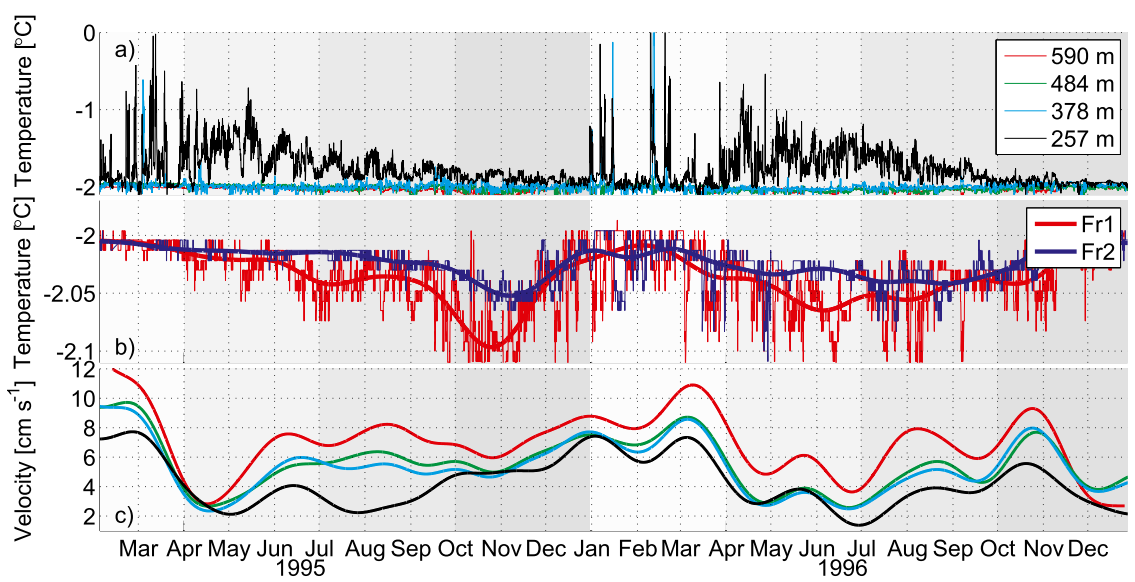

FIG. 9. Time series of (a) temperature records Fr1, (b) temperature records 20 mab at Fr1-Fr2, and (c) northward velocity recorded at Fr1. Thin lines are unfiltered data, and thick lines are lowpass filtered using a fourth-order Butterworth filter with a cutoff period of 60 days. The legend in (a) is also valid for (c). Note that temperatures below 378-m depth are similar, and the records from 484 (green) to $590 \mathrm{~m}$ (red) are thus hidden by the record from 378-m depth (cyan) in (a).

$D_{T_{\min }}$, the depth of the isopycnals below it, and the depth at the location of the CTD profile.

\section{d. Seasonality in the plume region}

Moorings F3 (1998) and W2 (2010) were deployed at the 1637- and 1411-m isobaths, respectively, roughly $80 \mathrm{~km}$ west of the sill. The moorings were located in the main plume path and were surrounded by plume water roughly $60 \%$ of the time. Figure 11 compares the $\theta-S$ diagram for April-June and December-February with that of the whole deployment period. In March-May, the observations-both in 1998 and 2010 - are generally shifted toward the left; that is, they are slightly fresher than the annual mean, while the December-February

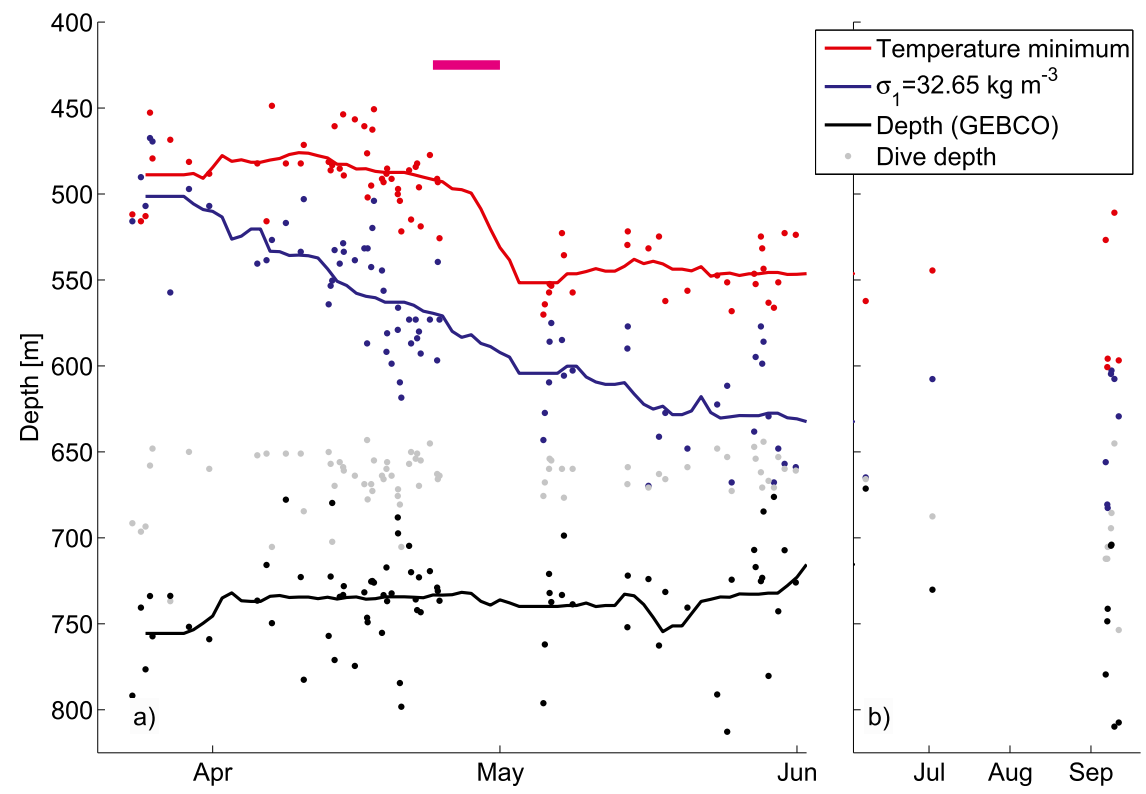

FIG. 10. Depth of the temperature min (red), the isopycnal $\sigma_{1}=32.65 \mathrm{~kg} \mathrm{~m}^{-3}$ (blue), the max depth of each profile (gray), and the depth at the location of the profile (black; from GEBCO) using seal data from the Filchner front (Box 2; see Fig. 1 for location) from (a) March to June and (b) June through September. The lines in (a) show 15-day running averages, and the magenta line marks the duration of the storm mentioned in the text. Only profiles deeper than $650 \mathrm{~m}$ are included in the analysis. Note that the scale of the $x$ axis differs from (a) to (b). 

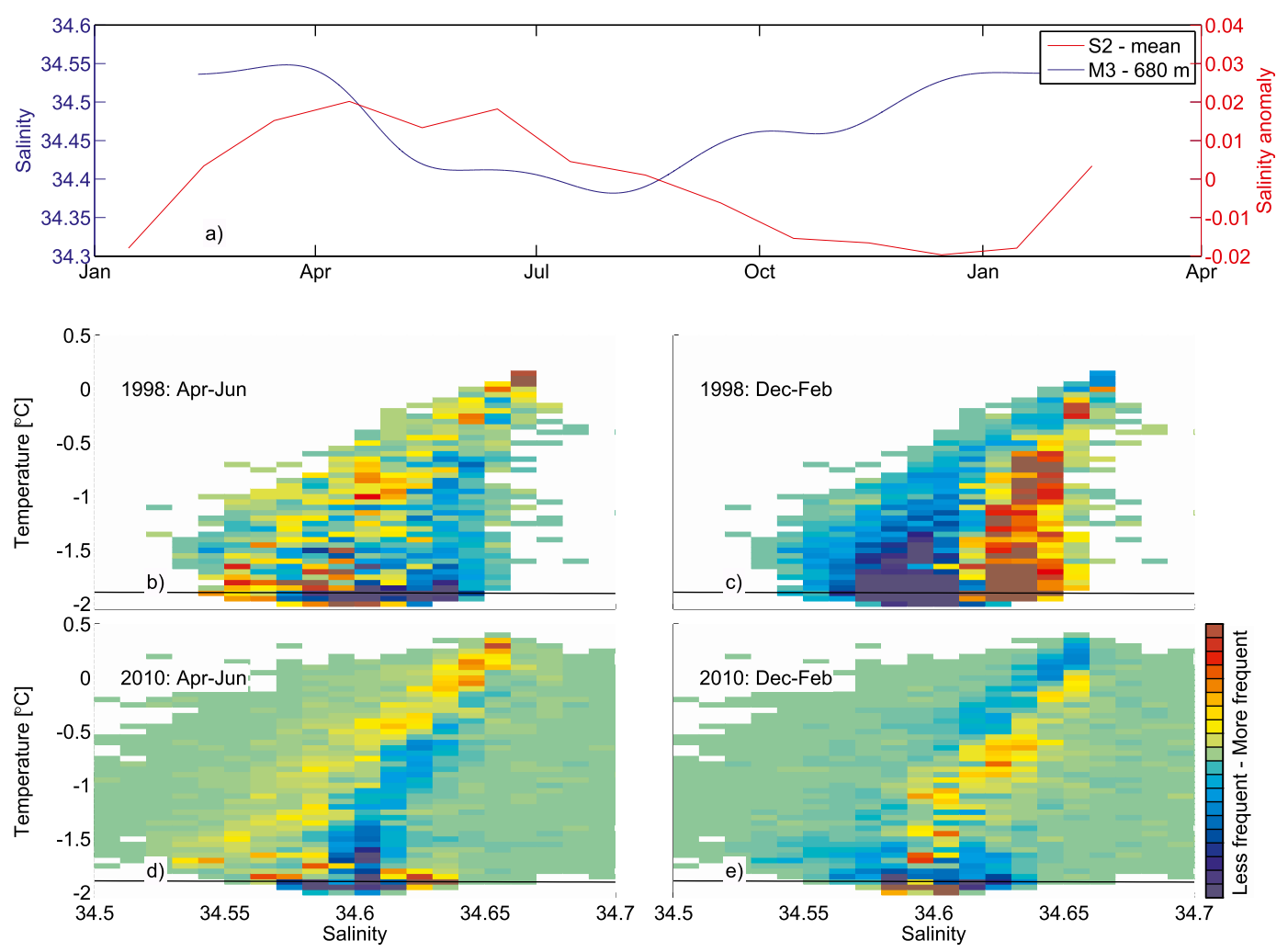

FIG. 11. (a) Salinity at M3 (680 m; 2009) and mean salinity anomaly at S2. Comparison of $\theta-S$ diagrams from F3 (b) April-June and (c) December-February 1998-99, and W2 (d) April-June and (e) December-February 2010-11 with the deployment mean. Each box $d S_{i} \times d \theta_{j}$ is colored to show the value of $\Delta n_{i, j}=n_{i, j, T} N_{T}^{-1}-n_{i, j, \Delta t} N_{\Delta t}^{-1}$, where $n_{i, j, \Delta t}$ is the number of observations falling within the box during a period $\Delta t, N$ is the total number of observations during that period, and where $T$ denotes the entire deployment. Positive (red) values hence indicate that observations in this box during this period is more frequent than on average, and negative (blue) values indicate that observations are less frequent than on average.

data are more saline. Contrary to the general freshening in April-June 2010, there is a higher occurrence of the most saline, near-freezing point water during this period. This is not seen during the same period in 1998. There is no seasonal signal in $\% t_{\text {plume }}$ (not shown).

\section{Discussion}

The five years of measurements from the Filchner sill reveal a seasonal signal in temperature with a maximum in April-May and a minimum in September-October, which is accompanied by a similar pattern in salinity (Fig. 5). At low temperatures, the density is dictated by salinity, and the change in density associated with the variability in the outflow salinity is about $0.03-0.04$ $\mathrm{kg} \mathrm{m}^{-3}$. In the weakly stratified deep Weddell Sea (where $d \sigma_{2} / d z$ is typically $\approx 2 \times 10^{-5} \mathrm{~kg} \mathrm{~m}^{-2}$ ), the seasonal difference in outflow density would - if other factors remain constant-result in a large $(>500 \mathrm{~m})$ difference in equilibrium depth, that is, in the depth to which the dense overflow plume can penetrate. The seasonality in the ambient density at the shelf break (Fig. 7b) and mesoscale variability (Jensen et al. 2013) can, however, be expected to greatly modify plume mixing and entrainment throughout the year and possibly have a greater impact on the final properties of the plume water than the source density. Indeed, observations from the plume region in 1998 and 2010 show a general freshening-despite high source salinity - of the plume water during AprilJune, clearly indicating the importance of the low-salinity ambient water and entrainment close to the shelf break during that period. Similarly, despite relatively low source salinity, the plume waters sampled at the continental slope are generally more saline during December-February when the ambient salinity at the shelf break is high. The seasonal variability of the source water, however, is captured in the densest and relatively unmixed plume waters. This is the case in, for example, April-June 2010, when the coldest plume water is more saline than on average, reflecting the concurrent high salinity at the sill. 
Returning to the sill and S2, the $\theta-S$ relation (Fig. 2) shows that the seasonality, at least partly, is caused by admixture of a warmer, more saline water mass. Because the MWDW is relatively less saline, we hypothesize that this water mass is the HSSW from the Berkner Bank. It should be noted that the use of Gade lines to detect admixture of other water masses has obvious caveats. First, admixture of HSSW with salinity close to the ISW source salinity $S_{0}$ will not be detected, and second, mixture of ISW with different $S_{0}$ will not in general follow a Gade line. At the sill of the Filchner Depression, however, we are confident that the deviation from the Gade line in the mooring and CTD data is due to HSSW admixture. The apparent absence of an HSSW signal in 2009 might be due to a lower than normal HSSW salinity that is close to $S_{0}$. With the exceptions of the years following the stranding of two large icebergs on the Berkner Bank (see introduction), HSSW from the Berkner Bank has been observed (during summer) at the bottom of the Filchner Depression (N98). The impact of the HSSW is potentially twofold; it mixes with the ISW, directly increasing the temperature and salinity of the overflow, but the ISW is also "lifted" up as the Filchner Depression is filled from below with HSSW from the Berkner Bank. Denser and warmer ISW can then flow over the sill. To lift the isopycnals by $100 \mathrm{~m}$ in the Filchner Depression, which has an area of about $4 \times$ $10^{4} \mathrm{~km}^{3}$, would require a flux of $0.3 \mathrm{~Sv}$ HSSW from the Berkner Bank during the freezing season. Unfortunately, there are no direct estimates of the HSSW production on the Berkner Bank or of the amount of HSSW entering the Filchner Depression. On the entire continental shelf in front of FRIS, an HSSW production of $2.8 \mathrm{~Sv}$ has been inferred (Nicholls et al. 2009). While the HSSW is formed during austral winter, its influence at S2 is most prominent in the summer and early autumn (February-May). We hypothesize that the lag is linked to the time it takes for the HSSW to build up and move from the generation site to $\mathrm{S} 2$. The distance between the center of the Berkner Bank and S2 is about $300 \mathrm{~km}$, and with expected velocities of a few centimeters per second, the advection time scale is on the order of 3-6 months.

The seal data compiled in the Filchner Depression in Box 1 (Fig. 8) confirm the seasonal presence of HSSW; CTD profiles from February through April show HSSW admixture in the lower part of the ISW layer while the profiles from May through September do not. At the Filchner Ice Shelf front, the observations from 2011 do suggest that the ISW layer (identified as the depth of the temperature minimum) and the isopycnals within the ISW layer are deepening from April to June, consistent with the draining of HSSW into the FRIS cavity. Part of the observed deepening might, however, be linked to strong easterly winds and Ekman pumping during a storm in April.

It is also possible that part of the seasonal variability originates in the ice shelf cavity. A seasonal signal in temperature linked to the seasonal inflow of HSSW into the Ronne Ice Shelf cavity has been observed at several locations within the cavity (Nicholls and Østerhus 2004; Jenkins et al. 2004). At Site 5, located $1300 \mathrm{~km}$ upstream and in the direct path followed by the ISW that later spills over the sill at S2 (see upper inset in Fig. 1), a seasonal signal with an amplitude of $0.06^{\circ} \mathrm{C}$ has been observed (Nicholls and Østerhus 2004). The numerical model by Jenkins et al. (2004) shows a reduction in the net flux of ISW out from the cavity in the Filchner Depression in midwinter (September-October), when the circulation in the depression is disrupted by convection. The model results, together with the variability in the northward velocity observed at Fr1 and the seasonality at Site 5, suggest that the outflow from the cavity and the circulation within the Filchner Depression vary with the seasons, although the observations are much too scarce to explore this in further detail.

Recent modeling efforts (Wang et al. 2012) suggest a seasonality of about $10 \%$ in the overflow volume flux across the sill of the Filchner Depression as a result of the seasonally varying density off the shelf: the modeled minimum occurs during austral summer and the maximum in September, slightly later than the observed maximum in $\Delta \rho_{\text {plume }}$. The density difference between the plume and the ambient inferred from the moored instruments (Fig. 7b) doubles from December to June, suggesting a potential doubling of the geostrophic outflow velocity. This is not observed. The velocity records from the sill do not show a discernible seasonal signal. The mooring just behind the sill (Fr1) does, however, show a seasonal signal with an observed maximum in northward flow during austral summer (Fig. 9c). The water flowing northward past Fr1 is-because there is no return flow observed on the western side of the depression (Fr2; F04)-likely to flow across the sill and contribute to the outflow. The seasonality observed at Fr1 may hence suggest that during the Fr1 deployment (1995-96) there was a seasonality also in the outflow across the sill with a maximum in austral summer. If so, the seasonal variability in outflow was out of phase with that expected from the seasonality of $\Delta \rho_{\text {plume }}$. The moorings Fr1-Fr2 were, however, deployed during a period when the giant icebergs stranded on the Berkner Bank greatly influenced the circulation in the region. Generally, the observations compiled here suggest that factors other than the shelf break density and $\Delta \rho_{\text {plume }}$ control the overflow. A more extensive array of moorings, in combination with more realistic 
numerical models, is needed to elucidate the dynamics in the region.

Our results imply a seasonally changing composition of the Filchner overflow, with a lower percentage of ISW (and thus less glacial meltwater) and more HSSW in April-May than in September-October. This will directly influence the chemical signature of the overflow water and introduce a seasonality in, for example, the $\delta^{18} \mathrm{O}$ ratio and ${ }^{4} \mathrm{He}$ concentration that depend on the concentration of glacial meltwater (Schlosser et al. 1990). Caution must therefore be taken when using such tracer and data from the Filchner overflow to estimate, for example, the formation rates of deep water in the Weddell Sea (Weppernig et al. 1996). The salinity and the amount of HSSW produced on the Berkner Bank are likely to vary interannually-for example, as a result of changing wind patterns related to the southern annular mode (Lefebvre 2004; Timmermann et al. 2002) and local conditions such as stranded icebergs (N98) — directly influencing, at least in the austral autumn, the properties of the Filchner overflow.

Observations in the vicinity of the Orkney Passage, the major gateway channeling WSDW out from the Weddell Sea, show a seasonal oscillation in temperature and salinity (Fig. 2; Gordon et al. 2010). This variability is tentatively explained as the result of seasonal release of HSSW from the continental shelves in the western Weddell Sea (Gordon et al. 2010; McKee et al. 2011) or by influences from the seasonally varying Weddell Gyre along the dense water path (Fahrbach et al. 2001; Wang et al. 2012). The Filchner overflow is believed to contribute mainly to the WSBW that does not escape directly through the Orkney Passage (Gordon 1998; Fahrbach et al. 1995), and it seems unlikely that the seasonality observed at the Filchner sill and that in the Orkney Passage are directly linked. The influence of a seasonally changing density at the shelf break on the plume properties, however, might be of importance also for sources of dense water farther west that contribute directly to the Orkney outflow.

\section{Conclusions}

Observations from the Filchner overflow show a seasonal variation in salinity and temperature but, contrary to results from numerical modeling (Kida 2011; Wang et al. 2012), no seasonality in outflow velocity. Temperature and salinity reach a maximum in April and the seasonal variability in density is about $0.03-0.04 \mathrm{~kg} \mathrm{~m}^{-3}$. The seasonality of the source water is still distinguishable in the plume region downstream of the sill at 1400$1600-m$ depth, but only in the densest plume water that has experienced little entrainment during its descent.
Lighter plume water, more diluted by the entrainment of ambient water at the shelf break and on the slope, show seasonality in salinity (and thus density) that is related to the seasonally changing properties of the water at the shelf break. The varying properties of the outflow are, at least partly, due to the seasonal admixture of HSSW from the Berkner Bank. The data suggest, however, that seasonal changes in the hydrography and circulation within the Filchner Depression and in the outflow of ISW from the ice shelf cavity also might be important.

Acknowledgments. The authors are grateful to the crew and scientist involved in collecting data, to P. Abrahamsen for preparing and providing the GIANT-RISOC data, and to K. Daae for preparing the data from W2. This study was funded through the Norwegian Research council funded projects BIAC and WEDDELL. Comments from two anonymous reviewers helped improve the manuscript and were greatly appreciated.

\section{REFERENCES}

Abrahamsen, E. P., B. Hansen, and C. Moore, 2003: GIANTSRISOC cruise to the southeastern Weddell Sea on R.R.S. Shackleton. British Antarctic Survey Tech. Rep., 1-27 pp.

Årthun, M., K. W. Nicholls, K. Makinson, M. A. Fedak, and L. Boehme, 2012: Seasonal inflow of warm water onto the southern Weddell Sea continental shelf, Antarctica. Geophys. Res. Lett., 39, L17601, doi:10.1029/2012GL052856.

,$- \ldots$, and L. Boehme, 2013: Wintertime water mass modification near an Antarctic Ice Front. J. Phys. Oceanogr., 43, 359-365, doi:10.1175/JPO-D-12-0186.1.

Boehme, L., P. Lovell, M. Biuw, F. Roquet, J. Nicholson, S. E. Thorpe, M. P. Meredith, and M. Fedak, 2009: Technical note: Animal-borne CTD-satellite relay data loggers for real-time oceanographic data collection. Ocean Sci. Discuss., 6, 12611287, doi:10.5194/osd-6-1261-2009.

Carmack, E. C., and T. D. Foster, 1975: Circulation and distribution of oceanographic properties near the Filchner Ice Shelf. Deep-Sea Res. Oceanogr. Abstr., 22, 77-90, doi:10.1016/ 0011-7471(75)90097-2.

Darelius, E., 2013: Cruise ES060 with R.R.S. Ernest Shackleton. University of Bergen Geophysical Institute Tech. Rep., 33 pp. _, and A. Wåhlin, 2007: Downward flow of dense water leaning on a submarine ridge. Deep-Sea Res. I, 54, 1173-1188, doi:10.1016/j.dsr.2007.04.007.

— L. H. Smedsrud, S. Østerhus, A. Foldvik, and T. Gammelsrød, 2009: Structure and variability of the Filchner overflow plume. Tellus, 61, 446-464, doi:10.1111/j.1600-0870.2009.00391.x.

Fahrbach, E., G. Rohardt, N. Scheele, M. Schröder, V. Strass, and A. Wisotzki, 1995: Formation and discharge of deep and bottom water in the northwestern Weddell Sea. J. Mar. Res., 53, 515-538, doi:10.1357/0022240953213089.

_ S. Harms, G. Rohardt, M. Schröder, and R. A. Woodgate, 2001: Flow of bottom water in the northwestern Weddell Sea. J. Geophys. Res., 106 (C2), 2761-2778, doi:10.1029/2000JC900142.

Foldvik, A., and Coauthors, 2004: Ice shelf water overflow and bottom water formation in the southern Weddell Sea. J. Geophys. Res., 109, C02015, doi:10.1029/2003JC002008. 
Foster, T. D., and E. C. Carmack, 1976: Frontal zone mixing and Antarctic Bottom Water formation in the southern Weddell Sea. Deep-Sea Res. Oceanogr., 23, 301-317, doi:10.1016/ 0011-7471(76)90872-X.

Gade, H., 1979: Melting of ice in sea water: A primitive model with application to the Antarctic Ice Shelf and icebergs. J. Phys Oceanogr., 9, 189-198, doi:10.1175/1520-0485(1979)009<0189: MOIISW $>2.0 . \mathrm{CO} ; 2$.

Gammelsrød, T., and N. Slotsvik, 1981: Hydrographic and current measurements in the southern Weddell Sea 1979/80. Polarforschung, 51, 101-111.

_ , and Coauthors, 1994: Distribution of water masses on the continental shelf in the southern Weddell Sea. The Polar Oceans and Their Role in Shaping the Global Environment, Geophys. Monogr., Vol. 85, Amer. Geophys. Union, 159-176.

Gill, A. E., 1973: Circulation and bottom water production in the Weddell Sea. Deep-Sea Res. Oceanogr. Abstr., 20, 111-140, doi:10.1016/0011-7471(73)90048-X.

Gordon, A. L., 1998: Western Weddell Sea thermohaline stratification. Ocean, Ice and Atmosphere: Interactions at the Antarctic Continental Margin, Geophys. Monogr., Vol. 75, Amer. Geophys. Union, 215-240.

_ , B. Huber, D. C. McKee, and M. Visbeck, 2010: A seasonal cycle in the export of bottom water from the Weddell Sea. Nat. Geosci., 3, 551-556, doi:10.1038/ngeo916.

Grosfeld, K., M. Schröder, E. Fahrbach, R. Gerdes, and A. Mackensen, 2001: How iceberg calving and grounding change the circulation and hydrography in the Filchner Ice Shelf-Ocean System. J. Geophys. Res., 106 (C5), 9039-9055, doi:10.1029/2000JC000601.

Jenkins, A., 1999: The impact of melting ice on ocean waters. J. Phys. Oceanogr., 29, 2370-2381, doi:10.1175/1520-0485(1999)029<2370: TIOMIO $>2.0 . \mathrm{CO} ; 2$.

-, D. M. Holland, K. W. Nicholls, M. Schröder, and S. Østerhus, 2004: Seasonal ventilation of the cavity beneath FilchnerRonne Ice Shelf simulated with an isopycnic coordinate ocean model. J. Geophys. Res., 109, C01024, doi:10.1029/2001JC001086.

Jensen, M. F., I. Fer, and E. Darelius, 2013: Low frequency variability on the continental slope of the southern Weddell Sea J. Geophys. Res. Oceans, 118, 4256-4272, doi:10.1002/jgrc.20309.

Johnson, G. C., 2008: Quantifying Antarctic Bottom Water and North Atlantic Deep Water volumes. J. Geophys. Res., 113, C05027, doi:10.1029/2007JC004477.

Kida, S., 2011: The impact of open oceanic processes on the Antarctic Bottom Water outflows. J. Phys. Oceanogr., 41, 19411957, doi:10.1175/2011JPO4571.1.

Lefebvre, W., 2004: Influence of the southern annular mode on the sea ice-ocean system. J. Geophys. Res., 109, C09005, doi:10.1029/2004JC002403.
McKee, D. C., X. Yuan, A. L. Gordon, B. Huber, and Z. Dong, 2011: Climate impact on interannual variability of Weddell Sea Bottom Water. J. Geophys. Res., 116, C05020, doi:10.1029/ 2010JC006484.

Meredith, M. P., 2013: Replenishing the abyss. Nat. Geosci., 6, 166167, doi:10.1038/ngeo1743.

Nicholls, K. W., and S. Østerhus, 2004: Interannual variability and ventilation timescales in the ocean cavity beneath FilchnerRonne Ice Shelf, Antarctica. J. Geophys. Res., 109 (C4), C04014, doi:10.1029/2003JC002149.

K. Makinson, and M. R. Johnson, 2001: Oceanographic conditions south of Berkner Island, beneath Filchner-Ronne Ice Shelf, Antarctica. J. Geophys. Res., 106 (C6), 1148111492, doi:10.1029/2000JC000350.

,,,--- T. Gammelsrød, and E. Fahrbach, 2009: Iceocean processes over the continental shelf of the southern Weddell Sea, Antarctica: A review. Rev. Geophys., 47, RG3003, doi:10.1029/2007RG000250.

Nøst, O. A., S. Østerhus, and A. Nøst, 1998: Impact of grounded icebergs on the hydrographic conditions near the Filchner Ice Shelf. Ocean, Ice, and Atmosphere: Interaction at the Antarctic Continental Margin, Geophys. Monogr., Vol. 75, Amer. Geophys. Union, 267-284.

Ohshima, K. I., and Coauthors, 2013: Antarctic Bottom Water production by intense sea-ice formation in the Cape Darnley Polynya. Nat. Geosci., 6, 235-240, doi:10.1038/ngeo1738.

Schlosser, P., R. Bayer, A. Foldvik, T. Gammelsrød, G. Rohardt, and K. O. Munnich, 1990: Oxygen 18 and helium as tracers of ice shelf water and water ice interaction in the Weddell Sea. J. Geophys. Res., 95 (C3), 3253-3263, doi:10.1029/ JC095iC03p03253.

Strand, K. O., 2011: Variations of the ice shelf water in the southern Weddell Sea, Antarctica. M. S. thesis, Geophysical Institute, University of Bergen, $59 \mathrm{pp}$.

Sverdrup, H., 1954: The currents off the coast of Queen Maud Land. Nor. Geogr. Tidsskr., 14 (1), 239-249, doi:10.1080/ 00291955308542731.

Timmermann, R., H. H. Hellmer, and A. Beckmann, 2002: Simulations of ice-ocean dynamics in the Weddell Sea 2. Interannual variability 1985-1993. J. Geophys. Res., 107 (C3), doi:10.1029/2000JC000742.

Wang, Q., S. Danilov, E. Fahrbach, J. Schröter, and T. Jung, 2012: On the impact of wind forcing on the seasonal variability of Weddell Sea Bottom Water transport. Geophys. Res. Lett., 39, L06603, doi:10.1029/2012GL051198.

Weppernig, R., P. Schlosser, S. Khatiwala, and R. G. Fairbanks, 1996: Isotope data from Ice Station Weddell: Implications for deep water formation in the Weddell Sea. J. Geophys. Res., 101 (C11), 25 723-25 739, doi:10.1029/96JC01895. 